\title{
Hafnium isotope variations in Bure volcanic rocks from the northwestern Ethiopian volcanic province: a new insight for mantle source diversity
}

\author{
Daniel MeSheShA* and Ryuichi SHINJO** \\ *Geological Survey of Ethiopia, Addis Ababa, P.O. Box 2302, Ethiopia \\ ** Department of Physics and Earth Sciences, University of the Ryukyus, \\ Senbaru 1, Nishihara, Okinawa 903-0213, Japan
}

\begin{abstract}
This paper presents new hafnium isotope data for the Bure volcanic rocks from the northwestern Ethiopian plateau to constrain the nature of mantle sources within the broad mantle upwelling. The ${ }^{176} \mathrm{Hf} /{ }^{177} \mathrm{Hf}$ values range from $0.282901(\varepsilon \mathrm{Hf}=4.79)$ to $0.283206(\varepsilon H f=15.71)$ for the Oligocene transitional tholeiite and 0.282915 $(\varepsilon \mathrm{Hf}=5.45)$ to $0.283069(\varepsilon \mathrm{Hf}=10.85)$ for the alkaline basalts; these ratios are distinct from MORB but typical to OIB sources. The $\varepsilon H f$ values correlate positively with $\varepsilon N d$. The scattered variation between $\varepsilon H f$ and contamination indices (such as $\mathrm{Nb} / \mathrm{La}$ and $\mathrm{Ce} / \mathrm{Pb}$ ) for the transitional tholeiites implies that most tholeiitic basalts are affected by crustal contamination processes. Components $1(\mathrm{C} 1)$ and $2(\mathrm{C} 2)$, which are proposed to be the endmember components for the Afar mantle plume, have a Hf isotopic signature of $\varepsilon \mathrm{Hf}=15-17$ and 5-9, respectively. The diversity of these compositions relies on the proportion of recycled materials in the deep source, its formation age, and proportion of sediments relative to oceanic crust in the recycled materials.
\end{abstract}

Keywords: East African rift, ${ }^{176} \mathrm{Hf} /{ }^{177} \mathrm{Hf}$ isotope, Crustal contamination, Continental flood basalts

\section{INTRODUCTION}

The distribution and timing of magmatism and uplift of the northwestern Ethiopian plateau have been widely attributed to the impact of the Afar mantle plume head impinged beneath the lithosphere at $~ 30$ Ma (e.g., Hofmann et al., 1997; Pik et al., 1998, 1999; Ukstins et al., 2002); its origin could be linked along a southwesterly direction to the African Superplume beneath Southern Africa (Kieffer et al., 2004; Furman, 2007; Meshesha and Shinjo, 2008).

A number of previous studies have focused on the trace elemental and $\mathrm{Sr}-\mathrm{Nd}-\mathrm{Pb}$ (and few-He) isotopic compositions of mafic lavas to assess the spatial and temporal variation of the mantle source composition (e.g., Pik et al., 1998, 1999; Kieffer et al., 2004; Meshesha and Shinjo, 2007). For instance, Pik et al. (1999) identified two distinct mantle components for the Oligocene continental flood basalts (CFBs) at the northwestern Ethiopian plateau: (a) an oceanic island basalt (OIB)-like mantle plume component $\left({ }^{87} \mathrm{Sr} /{ }^{86} \mathrm{Sr}=\sim 0.704 ;{ }^{143} \mathrm{Nd} /{ }^{144} \mathrm{Nd}=\right.$

doi:10.2465/jmps.090427a

R. Shinjo, rshinjo@sci.u-ryukyu.ac.jp Corresponding author $\left.\sim 0.51295 ;{ }^{206} \mathrm{~Pb} /{ }^{204} \mathrm{~Pb}=\sim 18.8\right)$ represented by high $-\mathrm{TiO}_{2}$ (HT2-type) basalts with high ${ }^{3} \mathrm{He} /{ }^{4} \mathrm{He}(19.6 \mathrm{Ra} ; 1 \mathrm{Ra}=$ atmospheric ${ }^{3} \mathrm{He} /{ }^{4} \mathrm{He}$ composition; Marty et al., 1996); and (b) a depleted mantle component, either intrinsic to the plume or entrained in the plume head $\left({ }^{87} \mathrm{Sr} r{ }^{86} \mathrm{Sr}=\sim 0.7033\right.$; ${ }^{143} \mathrm{Nd} /{ }^{144} \mathrm{Nd}=\sim 0.5130 ;{ }^{206} \mathrm{~Pb} / 204 \mathrm{~Pb}=\sim 18.6$ ) as a primary source for the crustal-contaminated low- $\mathrm{TiO}_{2}$ (LT-type) basalts. On the other hand, a depleted asthenospheric (DM) and enriched lithospheric mantle (EMI-EMII) components have been suggested as sources for the Southern Yemen CFBs (Chazot and Bertrand, 1993). However, a detailed investigation of $\mathrm{Sr}-\mathrm{Nd}-\mathrm{Pb}-\mathrm{O}$ isotopic and trace element compositions for Western Yemen CFBs (Baker et al., 1996, 2000) suggested that the upper and lower crustal contamination of the Afar plume-derived magmas play a key role in the geochemical variation of the East Africa CFBs.

More recently, Furman (2007) proposed a plume source with isotopic signatures analogous to those observed in some OIBs, including high ${ }^{3} \mathrm{He} /{ }^{4} \mathrm{He}$ values, present throughout the Ethiopian Rift and the Afar region.

Meshesha and Shinjo $(2004,2007)$ also reported petrological and geochemical studies for Oligocene CFBs 


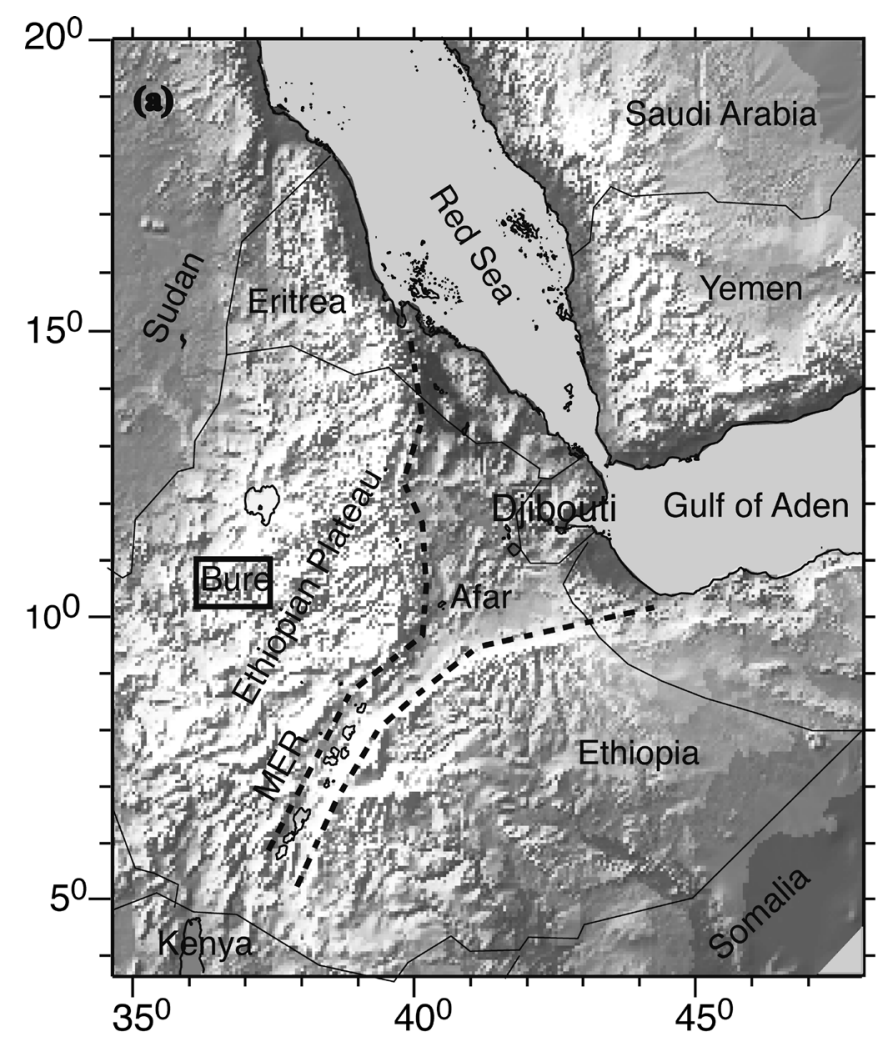

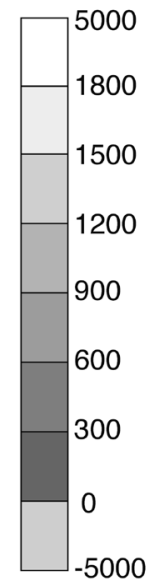

Elevation (m)

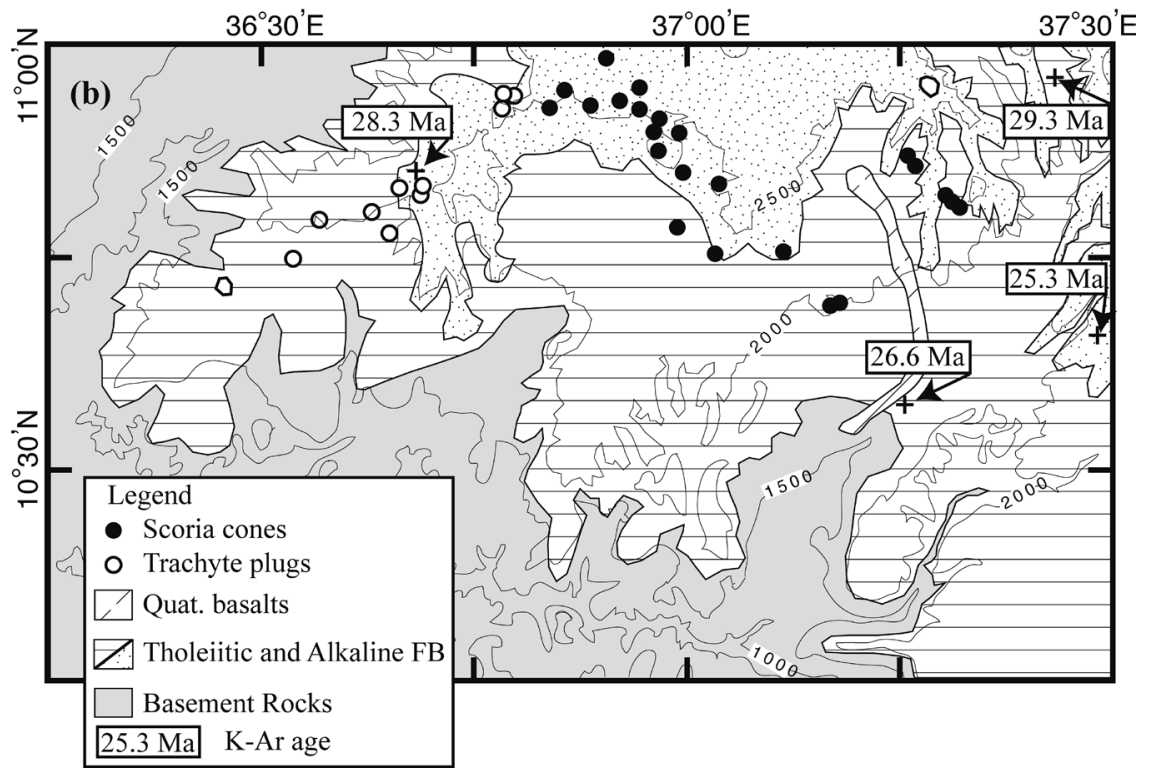

Figure 1. (a) Shaded relief map of East Africa and Arabia (ETOPO30) illustrating the position of the Gulf of Aden oceanic rift, Red Sea oceanic rift, East African Rift System (bold dashed lines), and study area (Bure). MER, Main Ethiopian Rift. (b) Simplified geological map of the Bure area. Topographic contour lines (interval $=500 \mathrm{~m}$ ) are also indicated. K-Ar ages are obtained from Meshesha and Shinjo (2007). FB, flood basalts and Basement rocks include Precambrian gneisses, low-grade rocks, and granitoids.

(29-25 Ma) and Quaternary alkaline basalts from the Bure area in the northwestern Ethiopian plateau (Fig. 1). The Bure CFBs consist of transitional tholeiitic basalts and alkaline basalts. The transitional tholeiites are hypersthenequartz normative, having relatively unfractionated chondrite-normalized rare earth element (REE) patterns, lower incompatible trace element abundance, and restricted range of isotopic ratios $\left({ }^{87} \mathrm{Sr} /{ }^{86} \mathrm{Sr}=0.70329-0.70429\right.$; $\left.{ }^{143} \mathrm{Nd} /{ }^{144} \mathrm{Nd}=0.51281-0.51304\right)$ coupled with large rang- es of ${ }^{206} \mathrm{~Pb} /{ }^{204} \mathrm{~Pb}(18.36-19.08)$. In contrast, the alkaline flood basalts are nepheline-olivine normative with highly fractionated REE patterns, higher incompatible trace element abundance, relatively lower $\mathrm{Sr}-\mathrm{Nd}$ isotopic ratios $\left({ }^{87} \mathrm{Sr} /{ }^{86} \mathrm{Sr}=0.70311-0.70363 ;{ }^{143} \mathrm{Nd} /{ }^{144} \mathrm{Nd}=0.51279-\right.$ 0.51288 ), and distinctly radiogenic ${ }^{206} \mathrm{~Pb} /{ }^{204} \mathrm{~Pb}(19.45-$ 19.83), except the two samples (18.42 and 18.64) that overlap with the range of ${ }^{206} \mathrm{~Pb} /{ }^{204} \mathrm{~Pb}$ of transitional basalts. Although most of the transitional tholeiite basalts 
have geochemical compositions that are substantially modified by crustal contamination during the ascent of plume-related magma, Meshesha and Shinjo (2007) identified two mantle plume components: (1) an isotopically depleted component that is intrinsic to the plume as a source for the transitional tholeiite basalts and (2) a plume component having radiogenic $\mathrm{Pb}$-isotopes as a source for the alkaline basalts. The latter one is isotopically dissimilar to the composition frequently referred as typical for the Oligocene Afar mantle plume by Pik et al. (1999). Thus, Meshesha and Shinjo (2008) discussed the heterogeneous nature of the Afar mantle plume and proposed several end-member plume components in the upwelling zone of the African Superplume. Two plume components identified in the Bure rocks (Meshesha and Shinjo, 2007) correspond to components $1(\mathrm{C} 1)$ and $2(\mathrm{C} 2)$ in the framework of end-member compositions by Meshesha and Shinjo (2008).

In this paper, we present results of Hf isotopic analyses of the Bure volcanic rocks that were analyzed in Meshesha and Shinjo (2007). A new Hf isotope dataset provides additional geochemical constraints on endmember components for the Afar mantle plume. Despite considerable published $\mathrm{Sr}-\mathrm{Nd}-\mathrm{Pb}$ (and, to a lesser extent, $\mathrm{He}$ ) isotopic data for the Ethiopian CFBs and the recent Main Ethiopian Rift volcanics, it is interesting to note that Hf isotopic data for these basalts has not been published; so far, we have found some documentations only in recent abstracts (e.g., Rooney et al., 2007, 2008; Nelson et al., 2008). Here, we will discuss the origin of the diversity of Hf isotopic compositions for Bure volcanic rocks, and attempt to constrain models of mantle source heterogeneity.

\section{GEOLOGICAL SETTING}

The Ethiopian volcanic province is composed of a Cenozoic basaltic pile with thicknesses varying from 700 to $2000 \mathrm{~m}$ at the plateau-rift margins (Berhe et al., 1987) and it covers an area of approximately $600000 \mathrm{~km}^{2}$ (Mohr, 1963; Mohr and Zanettin, 1988). Volcanism began with the eruption of 45-40 Ma basaltic lavas in southernmost Ethiopia (Davidson and Rex, 1980; WoldeGabriel et al., 1990; Ebinger et al., 1993; George et al., 1998; George and Rogers, 2002). Then, the main episode of CFB volcanism initiated during the Oligocene in the Ethiopian plateau, which is inferred to mark the first appearance of the Afar mantle plume head (e.g., Hofmann et al., 1997; Mohr and Zanettin, 1988; Pik et al., 1998, 1999; Ayalew et al., 2002; Coulie et al., 2003) or larger plumelet within the broad upwelling zone connected to the South African Superplume (Meshesha and Shinjo, 2008).

The CFB of the northwestern Ethiopian plateau is further subdivided into three main magma types, distinguished by their contrasting geochemical signatures (Pik et al., 1998, 1999): low-Ti basalts (LT-type) located in the northwestern part of the plateau and high-Ti basalts (HT1- and HT2-type) located in the eastern part of the plateau (see Fig. 1b of Pik et al., 1998, 1999). These flood basalts forming the northwestern Ethiopian plateau erupted in a short time interval $(<5 \mathrm{Ma})$ with the greatest eruption rates occurring from 31 to $28 \mathrm{Ma}$ (Hofmann et al., 1997; Pik et al., 1998; Ukstins et al., 2002; Meshesha and Shinjo, 2007). The Oligocene (29-25 Ma) Bure volcanic rocks are typical Ethiopian plateau CFBs, which are composed of transitional tholeiite and alkaline basalts (Fig. 1; Meshesha and Shinjo, 2007). A majority of the transitional tholeiite basalts falls in the LT-basalt field of Pik et al. (1998) (see Fig. 3b of Meshesha and Shinjo, 2007); however, the other transitional and alkaline basalts have higher and variable $\mathrm{TiO}_{2}$ contents that are scattered in fields of HT1 - and HT2-type basalts of Pik et al. (1998). The LTand HT-basalts of Pik et al. (1998) are indistinguishable in terms of alkali contents; most are plotted around the tholeiite/alkaline boundary line (e.g., Fig. 3 of Pik et al., 1998).

Subsequent activity is characterized by less voluminous and more alkaline shield-volcano-building episodes overlying the flood basalts, which gave rise to the development of, for example, Choke and Guguftu shield volcanoes in the northwestern Ethiopian plateau at $\sim 23 \mathrm{Ma}$ (Kieffer et al., 2004).

\section{ANALYTICAL METHODS}

Seventeen representative basaltic and two trachyte plug samples, which were previously analyzed for $\mathrm{Sr}-\mathrm{Nd}-\mathrm{Pb}$ isotopic compositions (Meshesha and Shinjo, 2007), are analyzed for Hf isotopes. About $0.5-1 \mathrm{~g}$ of whole-rock powders used in Meshesha and Shinjo (2007), which were prepared from carefully handpicked fresh rock chips, were dissolved in a concentrated $\mathrm{HNO}_{3}-\mathrm{HF}$ mixture with or without $\mathrm{HClO}_{4}$.

Chemical purification of Hf was conducted in a clean laboratory at the Department of Physics and Earth Sciences of the University of the Ryukyus. Hf is purified using two-step column separation with an Ln-Spec resin of Eichrome Technologies (Darien, IL, USA) in polypropylene columns (M- and S-size columns of Muromachi Technos Co., Ltd., Japan); the first column employs a $2.5-\mathrm{mL}$ resin bed and the second column, a $1.0-\mathrm{mL}$ resin volume. In the first column, the sample solution $(3 \mathrm{M} \mathrm{HCl})$ is loaded on the column, following the modified method described in Münker et al. (2002). Major elements and LREE are first removed from the column by introducing $3 \mathrm{M} \mathrm{HCl}$, 
Table 1. Hf-isotopic data for Bure volcanic rocks

\begin{tabular}{|c|c|c|c|c|c|c|c|c|c|c|c|}
\hline Samples & $\begin{array}{c}{ }^{176} \mathrm{Hf} /{ }^{177} \mathrm{Hf} \\
(\mathrm{MC}-\mathrm{ICP}-\mathrm{MS})\end{array}$ & $2 \mathrm{SE}$ & $\begin{array}{c}{ }^{176} \mathrm{Hf} /{ }^{177} \mathrm{Hf} \\
\text { (TIMS) }\end{array}$ & $2 \mathrm{SE}$ & $\begin{array}{c}\mathrm{Lu} \\
(\mathrm{ppm})\end{array}$ & $\begin{array}{c}\mathrm{Hf} \\
(\mathrm{ppm})\end{array}$ & ${ }^{176} \mathrm{Lu} /{ }^{177} \mathrm{Hf}$ & $\varepsilon_{\mathrm{Hf}}$ & ${ }^{143} \mathrm{Nd} /{ }^{144} \mathrm{Nd}_{\mathrm{n}}$ & $\varepsilon_{\mathrm{Nd}}$ & $\Delta \varepsilon_{\mathrm{Hf}}$ \\
\hline \multicolumn{12}{|c|}{ Quaternary trachyte plugs } \\
\hline TD-1136A2 & 0.283025 & 4 & 0.283032 & 17 & 2.10 & 32.2 & 0.0093 & 8.95 & 0.512867 & 4.47 & 0.56 \\
\hline Duplicate & 0.283029 & 7 & & & & & & & & & \\
\hline SM-113 & 0.282874 & 2 & 0.282880 & 22 & 1.05 & 24.3 & 0.0061 & 3.61 & 0.512792 & 3.00 & -2.44 \\
\hline \multicolumn{12}{|c|}{ Quaternary basalts (Alkaline) } \\
\hline TD-1003 & 0.283034 & 5 & 0.283013 & 32 & 0.23 & 2.62 & 0.0125 & 9.27 & 0.512879 & 4.70 & 0.52 \\
\hline SOG-3157 & 0.282996 & 2 & 0.283010 & 28 & 0.28 & 3.05 & 0.0130 & 7.92 & 0.512879 & 4.70 & -0.83 \\
\hline \multicolumn{12}{|c|}{ Oligocene alkaline basalts } \\
\hline TD-1034B & 0.283039 & 2 & 0.283029 & 21 & 0.60 & 6.89 & 0.0124 & 9.84 & 0.512857 & 4.44 & 1.50 \\
\hline SM-120 & 0.282915 & 1 & & & 0.43 & 4.84 & 0.0126 & 5.45 & 0.512823 & 3.90 & -2.03 \\
\hline Duplicate & 0.282907 & 3 & & & & & & & & & \\
\hline SOG-3091 & 0.282943 & 2 & & & 0.41 & 6.94 & 0.0084 & 6.52 & 0.512844 & 4.24 & -1.50 \\
\hline SOG-3005 & 0.283000 & 2 & & & 0.27 & 3.71 & 0.0103 & 8.50 & 0.512899 & 5.27 & -1.16 \\
\hline SOG-3043 & 0.283032 & 4 & & & 0.32 & 3.55 & 0.0128 & 9.58 & 0.512909 & 5.56 & -0.54 \\
\hline SM-172 & 0.283069 & 3 & 0.283082 & 41 & 0.45 & 4.35 & 0.0147 & 10.85 & 0.512902 & 5.31 & 1.13 \\
\hline \multicolumn{12}{|c|}{ Oligocene transitional tholeiite basalts } \\
\hline TD-1228A & 0.283185 & 4 & & & 0.55 & 5.04 & 0.0155 & 14.94 & 0.513019 & 7.47 & 1.78 \\
\hline Duplicate & 0.283179 & 3 & & & & & & & & & \\
\hline ASW-503 & 0.283024 & 2 & 0.283047 & 16 & 0.45 & 4.51 & 0.0142 & 9.27 & 0.512858 & 4.41 & 0.98 \\
\hline TL-253 & 0.283206 & 1 & & & 0.39 & 3.91 & 0.0142 & 15.71 & 0.513070 & 8.49 & 0.93 \\
\hline EH-235A & 0.283193 & 2 & & & 0.31 & 3.61 & 0.0122 & 15.29 & 0.513063 & 8.42 & 0.62 \\
\hline AN-201 & 0.282901 & 6 & & & 0.27 & 1.79 & 0.0214 & 4.79 & 0.512836 & 3.91 & -2.71 \\
\hline Duplicate & 0.282900 & 4 & & & & & & & & & \\
\hline MH-4510A & 0.283171 & 1 & 0.283160 & 17 & 0.70 & 7.37 & 0.0135 & 14.48 & 0.513008 & 7.32 & 1.56 \\
\hline MH-4521 & 0.283047 & 3 & & & 0.40 & 4.04 & 0.0141 & 10.09 & 0.512891 & 5.13 & 0.65 \\
\hline TD-1202 & 0.283076 & 4 & 0.283101 & 23 & 0.45 & 3.86 & 0.0166 & 11.07 & 0.512934 & 5.79 & 0.58 \\
\hline TD-1239 & 0.283099 & 4 & & & 0.32 & 2.09 & 0.0217 & 11.78 & 0.512915 & 5.61 & 1.58 \\
\hline Duplicate & 0.283100 & 4 & & & & & & & & & \\
\hline
\end{tabular}

2SE (standard error) corresponds to the last two digits.

$\mathrm{Lu}, \mathrm{Hf}$, and ${ }^{143} \mathrm{Nd} /{ }^{144} \mathrm{Nd}$ are obtained from Meshesha and Shinjo (2007).

${ }^{143} \mathrm{Nd} /{ }^{144} \mathrm{Nd}$ values are normalized relative to the ${ }^{143} \mathrm{Nd} /{ }^{144} \mathrm{Nd}$ ratio for La Jolla of 0.51186.

$\varepsilon \mathrm{Nd}$ and $\varepsilon \mathrm{Hf}$ values are calculated using $\mathrm{t}=27 \mathrm{Ma}$ and $0 \mathrm{Ma}$ for Oligocene basalts and Quaternary samples, respectively.

CHUR $_{(0 \text { Ma) }}$ values: ${ }^{143} \mathrm{Nd} /{ }^{144} \mathrm{Nd}=0.512638$ and ${ }^{147} \mathrm{Sm} /{ }^{144} \mathrm{Nd}=0.1967$ (Jacobsen and Wasserburg, 1980); ${ }^{176} \mathrm{Hf} /{ }^{177} \mathrm{Hf}=0.282772$ and ${ }^{176} \mathrm{Lu} /$

${ }^{177} \mathrm{Hf}=0.0332$ (Blichert-Toft and Albarède, 1997a; Vervoort and Blichert-Toft, 1999).

${ }^{176} \mathrm{Lu}$ decay constant is $1.983 \times 10^{-11} / \mathrm{y}$ (Bizzarro et al., 2003). $\Delta \varepsilon \mathrm{Hf}=\varepsilon \mathrm{Hf}-(1.59 \varepsilon \mathrm{Nd}+1.28)($ Chauval et al., 2008).

followed by HREE with $6 \mathrm{M} \mathrm{HCl}$ and $\mathrm{Ti}-\mathrm{Nb}-\mathrm{Zr}$ with $(2 \mathrm{M}$ $\mathrm{HCl}+0.1 \mathrm{M} \mathrm{HF})$. $\mathrm{Hf}$ is finally extracted with $(2 \mathrm{M} \mathrm{HCl}+$ $0.2 \mathrm{M} \mathrm{HF}$ ). After the $\mathrm{Hf}$ fraction from the first column was dried, the residue was re-dissolved with $0.4 \mathrm{ml}$ of $(2 \mathrm{M}$ $\mathrm{HCl}+0.1 \mathrm{M} \mathrm{HF}$ ) and then loaded on the second column. After Ti-Zr was washed out with $(2 \mathrm{M} \mathrm{HCl}+0.1 \mathrm{M} \mathrm{HF})$, $\mathrm{Hf}$ was eluted with $(2 \mathrm{~N} \mathrm{HCl}+0.2 \mathrm{M} \mathrm{HF})$. Our laboratory procedural blanks were typically less than $60 \mathrm{pg}$ for $\mathrm{Hf}$ and no blank correction was required for the isotope ratios measured.

$\mathrm{Hf}$ isotope ratios were measured by thermal ionization mass spectrometry (TIMS; Finnigan MAT 262) at the University of the Ryukyus and by multi-collector inductively coupled plasma mass spectrometry (MC-ICP-MS;
ThermoFinnigan Neptune) at the National Taiwan University (Table 1). For TIMS measurement, purified Hf was dissolved with $1 \mu \mathrm{l}$ of $0.2 \mathrm{M} \mathrm{HF}$ and loaded on a zone-refined Re double filament; then, $1 \mu \mathrm{l}$ of $1 \mathrm{M} \mathrm{H}_{3} \mathrm{PO}_{4}$ and $3 \mu \mathrm{l}$ of silica gel were added and dried down at $\sim 1.6$ A. The procedure for analyzing Hf by TIMS was that described in Nowell et al. (1998). Measurement by MCICP-MS is carried out in the static mode; all measured Hf isotopic ratios were corrected for $\mathrm{W}$ and $\mathrm{Ta}$, and $\mathrm{Lu}$ and $\mathrm{Yb}$ interferences on masses 180 and 176, respectively, by monitoring the isotopes ${ }^{182} \mathrm{~W}$ and ${ }^{181} \mathrm{Ta}$, and ${ }^{175} \mathrm{Lu}$ and ${ }^{173} \mathrm{Yb}$.

The measured ${ }^{176} \mathrm{Hf} /{ }^{177} \mathrm{Hf}$ ratios were corrected for isotope fractionation to ${ }^{179} \mathrm{Hf} /{ }^{177} \mathrm{Hf}=0.7325$ (Blichert-Toft 
et al., 1997b). During this study, the ${ }^{176} \mathrm{Hf} /{ }^{177} \mathrm{Hf}$ of JMC475 Hf standard gave a mean value of $0.282148 \pm 51$ $(2 \mathrm{SD} ; \mathrm{n}=26)$ for TIMS and $0.282142 \pm 17(2 \mathrm{SD} ; \mathrm{n}=14)$ for MC-ICP-MS measurements. The measured ${ }^{176} \mathrm{Hf} /{ }^{177} \mathrm{Hf}$ of the Ames Hf standard by MC-ICP-MS gave a mean value of $0.282139 \pm 8(2 \mathrm{SD}, \mathrm{n}=22)$; this was comparable to previously reported values of $0.282144 \pm 12(1 \mathrm{SD}, \mathrm{n}=$ 22; Ballentine et al., 1997) and 0.282160 (Lapen et al., 2004). The Hf isotope data reported in Table 1 are values normalized to JMC $-475{ }^{176} \mathrm{Hf} /{ }^{177} \mathrm{Hf}=0.28216$ (Nowell et al., 1998). Duplicate analyses of three samples, for which the values agree within $0.2-0.4$ EHf units, exhibited good reproducibility of the $\mathrm{MC}-\mathrm{ICP}-\mathrm{MS}$ analyses. In this paper, we use data obtained by MC-ICP-MS because of its good accuracy and wide coverage of samples.

\section{ANALYTICAL RESULTS}

New ${ }^{176} \mathrm{Hf} /{ }^{177} \mathrm{Hf}$ data and calculated $\varepsilon \mathrm{Hf}$ values, together with $\mathrm{Lu}$ and $\mathrm{Hf}$ contents and $\mathrm{Nd}$ isotopic compositions reported in Meshesha and Shinjo (2007), for Bure volcanic rocks from the northwestern Ethiopia plateau are presented in Table 1. The transitional tholeiite basalts have ${ }^{176} \mathrm{Hf} /$ ${ }^{177} \mathrm{Hf}$ ranging from $0.282901(\varepsilon \mathrm{Hf}=4.79$ ) to 0.283206 $(\varepsilon \mathrm{Hf}=15.71)$. Oligocene alkaline basalts have a limited range of ${ }^{176} \mathrm{Hf} /{ }^{177} \mathrm{Hf}[0.282915(\varepsilon \mathrm{Hf}=5.45)$ to 0.283069 $(\varepsilon \mathrm{Hf}=10.85)]$. Hf isotopes of Quaternary alkaline basalts are within the range of Oligocene alkaline basalts. Quaternary trachyte plug samples have the lowest ${ }^{176} \mathrm{Hf} /{ }^{177} \mathrm{Hf}$ (0.282874; $\varepsilon \mathrm{Hf}=3.61)$.

These data are plotted in the Hf-Nd isotopic correlation diagram (Fig. 2a) together with the previously published Hf-Nd isotope compositions for MORB (Chauvel and Blichert-Toft, 2001), St. Helena (Salters and White, 1998), and Yemen volcanic rocks (Bertrand et al., 2003). $\varepsilon$ Hf of the Oligocene Bure transitional tholeiite are positively correlated with $\varepsilon \mathrm{Nd}$; the trend is subparallel to the global Nd-Hf mantle array (Fig. 2a; $\varepsilon \mathrm{Hf}=1.59 \varepsilon \mathrm{Nd}+$ 1.28; Chauvel et al., 2008), and lies above the mantle array. The exception is sample $\mathrm{AN}-201$, which has noticeably low ${ }^{176} \mathrm{Hf} /{ }^{177} \mathrm{Hf}$. Excluding sample AN-201, the Bure transitional tholeiites exhibit a negative trend in $\mathrm{Hf}-\mathrm{Sr}$ and $\mathrm{Hf}-\mathrm{Pb}$ isotope diagrams (Figs. $2 \mathrm{~b}$ and $2 \mathrm{c}$ ). The $\mathrm{eNd}-$ $\varepsilon \mathrm{Hf}$ trend defined by the Oligocene Bure alkaline basalts is relatively steeper than the global mantle array (Fig. 2a). Except for two alkaline samples (TD-1034B and SM172), the remaining samples exhibited relatively lower ${ }^{87} \mathrm{Sr} /{ }^{86} \mathrm{Sr}$ and high $\mathrm{Pb}$-isotope ratios (Fig. 2c). There appear two groups on the $\varepsilon \mathrm{Hf}$ versus ${ }^{87} \mathrm{Sr} /{ }^{86} \mathrm{Sr}$ diagram (Fig. $2 \mathrm{~b}$ ), which roughly correspond to the transitional tholeiite and alkaline basalts, respectively, as also observed in the ${ }^{143} \mathrm{Nd} /{ }^{144} \mathrm{Nd}$ versus ${ }^{87} \mathrm{Sr} /{ }^{86} \mathrm{Sr}$ plot in Meshesha and Shinjo
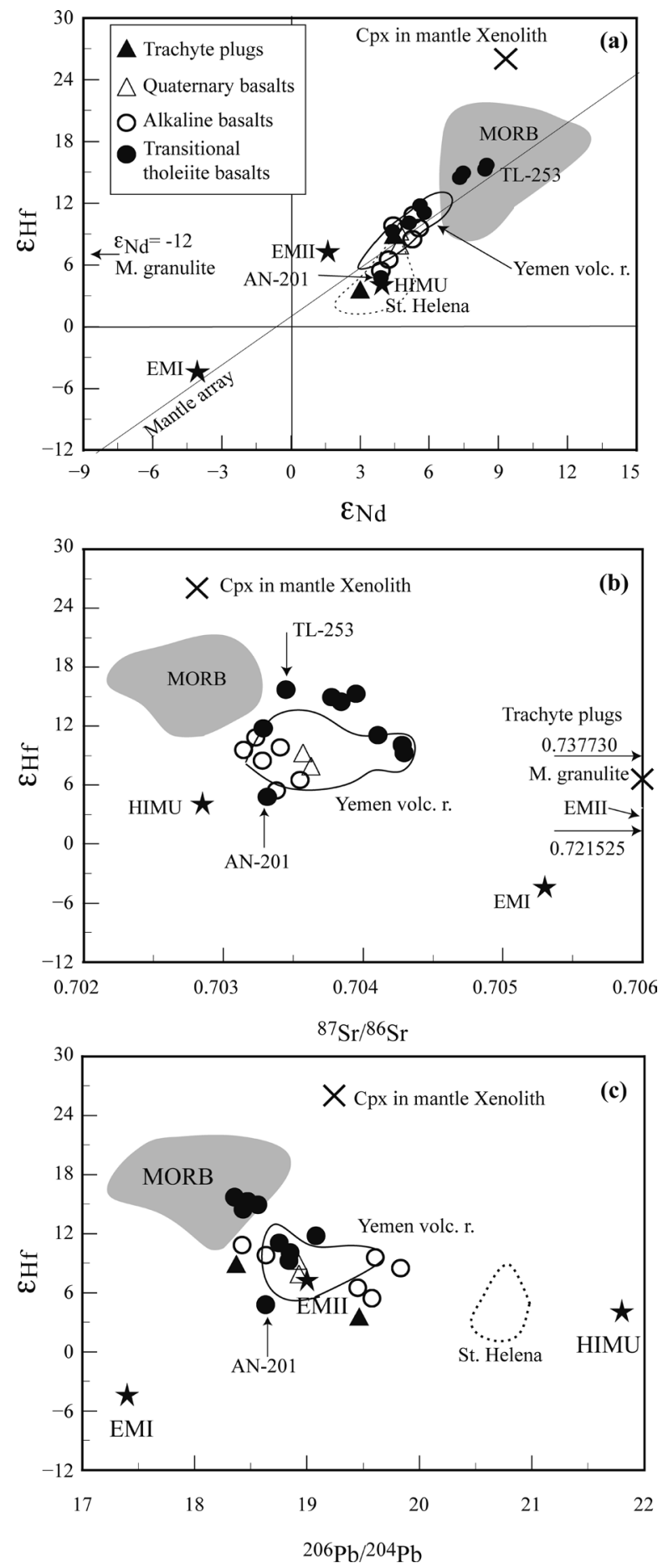

Figure 2. Plots of $\varepsilon \mathrm{Hf}$ versus $\varepsilon \mathrm{Nd}(\mathrm{a}),{ }^{87} \mathrm{Sr} /{ }^{86} \mathrm{Sr}$ (b), and ${ }^{206} \mathrm{~Pb} /{ }^{204} \mathrm{~Pb}$ (c) for Bure volcanic rocks, including previously published $\mathrm{Hf}$ isotope data for MORB (Chauvel and Blichert-Toft, 2001), St. Helena (Salters and White, 1998), Yemen volcanic rocks (Yemen volc. r.; Bertrand et al., 2003), average clinopyroxene composition in mantle xenolith (cpx in mantle xenolith; Shaw et al., 2007), and mafic granulite (M. granulite; Janney et al., 2005). HIMU, EMI, and EMII mantle end members are obtained from Armienti and Gasperini (2007), Salters and White (1998), and Zindler and Hart (1986). The mantle array is obtained from Chauvel et al. (2008). 


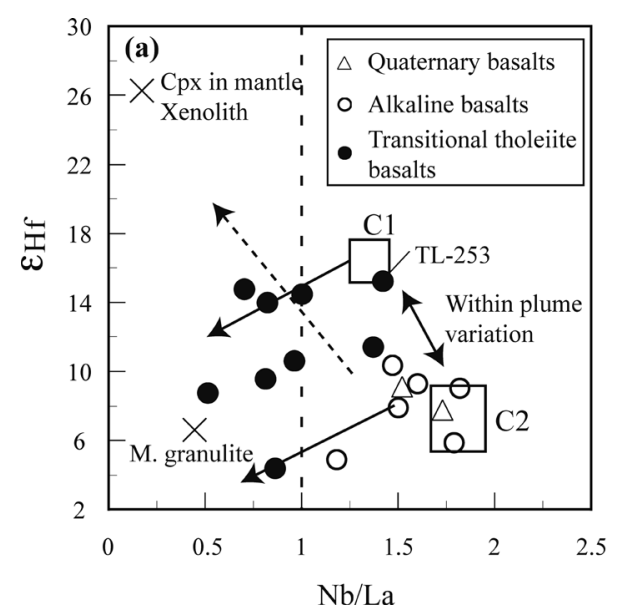

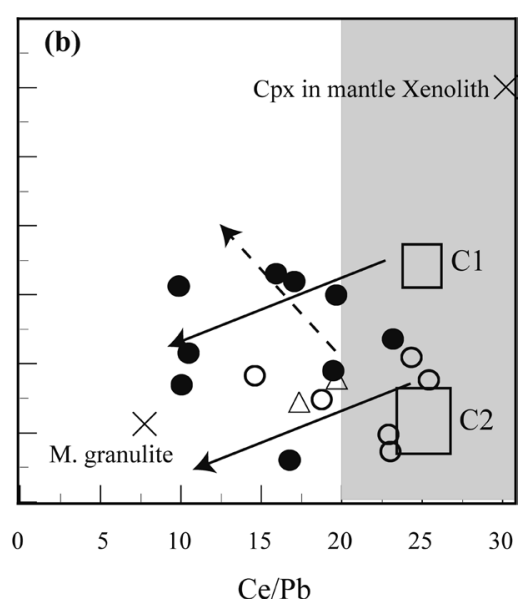

Figure 3. Plots of $\varepsilon \mathrm{Hf}$ versus (a) $\mathrm{Nb} /$ $\mathrm{La}$ and (b) $\mathrm{Ce} / \mathrm{Pb}$ for Bure volcanic rocks. Solid arrows indicate expected trends of crustal contamination. The average clinopyroxene composition in the mantle xenolith (cpx in mantle xenolith) from Jordan and the mean value of the South African mafic granulite (M. granulite) are obtained from Shaw et al. (2007) and Janney et al. (2005), respectively. Mantle plume components $(\mathrm{C} 1$ and $\mathrm{C} 2$ ) are obtained from Meshesha and Shinjo (2008).
(2007). The Quaternary basalts have an intermediate composition between that of Oligocene transitional tholeiite and alkaline basalts (Fig. 2b). Although two Quaternary trachyte samples have an $\mathrm{Hf}-\mathrm{Nd}-\mathrm{Pb}$ isotope composition similar to Oligocene basalts, their ${ }^{87} \mathrm{Sr} /{ }^{86} \mathrm{Sr}$ values are extremely high (0.72153 and 0.73773$)$, thus falling outside the range of Figure $2 \mathrm{~b}$. In general, the Bure volcanic rocks exhibit a broad overlap with the compositional field for the Yemen volcanic rocks (Bertrand et al., 2003).

\section{DISCUSSION}

$\mathrm{Sr}-\mathrm{Nd}-\mathrm{Pb}$ isotope data of the Bure volcanic rocks, coupled with incompatible trace element concentrations, have been previously used to discuss the magma differentiation processes and to investigate the nature of magma sources (Meshesha and Shinjo, 2007). Apart from the magma differentiation processes, Meshesha and Shinjo (2007) interpreted the variations of the geochemical compositions as a result of the variable mixing of three, geochemically distinct components: (1) isotopically depleted (but incompatible element-enriched) "intrinsic" plume component, (2) a plume component having radiogenic $\mathrm{Pb}$-isotope ratios (HIMU?), and (3) an enriched crustal component. Considering these three proposed components as the source of the Bure basalts, we examine ${ }^{176} \mathrm{Hf} /{ }^{177} \mathrm{Hf}$ variations observed in the Bure basalts in terms of crustal contamination and diversity of mantle plume components.

\section{Crustal contamination effect on $\mathrm{Hf}$ isotope ratios}

Meshesha and Shinjo (2007) pointed out that many transitional tholeiite basalts have geochemical compositions that are substantially modified by crustal contamination during the ascent of plume-related magmas; plume-related magmas are inferred to originate from mantle sources dominated by an isotopically depleted plume component.
However, the simple mixing calculations (see Fig. 9 in Meshesha and Shinjo, 2007) are only qualitatively consistent with the crustal assimilation model, probably due to either highly variable compositions of the Pan-African crustal materials or compositional diversity of mantle-derived magmas, or a combination of both factors.

Here, our new ${ }^{176} \mathrm{Hf} /{ }^{177} \mathrm{Hf}$ data coupled with indices of crustal contamination are used to examine the source of such variations in the genesis of transitional tholeiite basalts. The plots of $\varepsilon \mathrm{Hf}$ versus $\mathrm{Nb} / \mathrm{La}$ and $\mathrm{Ce} / \mathrm{Pb}$ (Fig. 3) exhibit rather scattered patterns for transitional tholeiites as compared to alkaline basalts. We utilize the ratios of $\mathrm{Nb} / \mathrm{La}$ and $\mathrm{Ce} / \mathrm{Pb}$ to discriminate a continental crust component from a mantle source component. Many transitional tholeiite basalts have lower $\mathrm{Nb} / \mathrm{La}$ and $\mathrm{Ce} / \mathrm{Pb}$ ratios, approaching the average crust values $(\mathrm{Nb} / \mathrm{La}=0.2-0.7$ and $\mathrm{Ce} / \mathrm{Pb}<5$; Taylor and McClennan, 1985; Rudnick and Geo, 2004), as compared to values of $\mathrm{Nb} / \mathrm{La} \geq 1.1$ (Armineti and Gasperini, 2007) and $\mathrm{Ce} / \mathrm{Pb}=25 \pm 5$ (Hofmann et al., 1986) for MORB and OIBs. Crustal contamination processes could produce a positively correlated trend in this diagram, because continental crustal materials generally have low $\varepsilon H f$ (mostly $<10$; e.g., Vervoort et al., 2000), for example, the average values of South African mafic granulite (Janney et al., 2005). Late Proterozoic (0.8-0.7 Ga) juvenile crust from northeast Sudan have similar $\varepsilon H f$ values of -0.57 to 7.78 (Vervoort and Blichert-Toft, 1999).

The scattered data distribution for transitional tholeiite basalts in Figure 3 can be attributed to the interaction of mantle-derived magmas, which originated from a plume mantle source having basically two distinct components, with a continental crust having lower Hf isotope, $\mathrm{Nb} / \mathrm{La}$, and $\mathrm{Ce} / \mathrm{Pb}$ ratios (solid arrows in Fig. 3). The scattered data plot for transitional tholeiite may also be partly due to heterogeneous nature of Hf isotopes of crustal materials. The two inferred mantle plume components in 

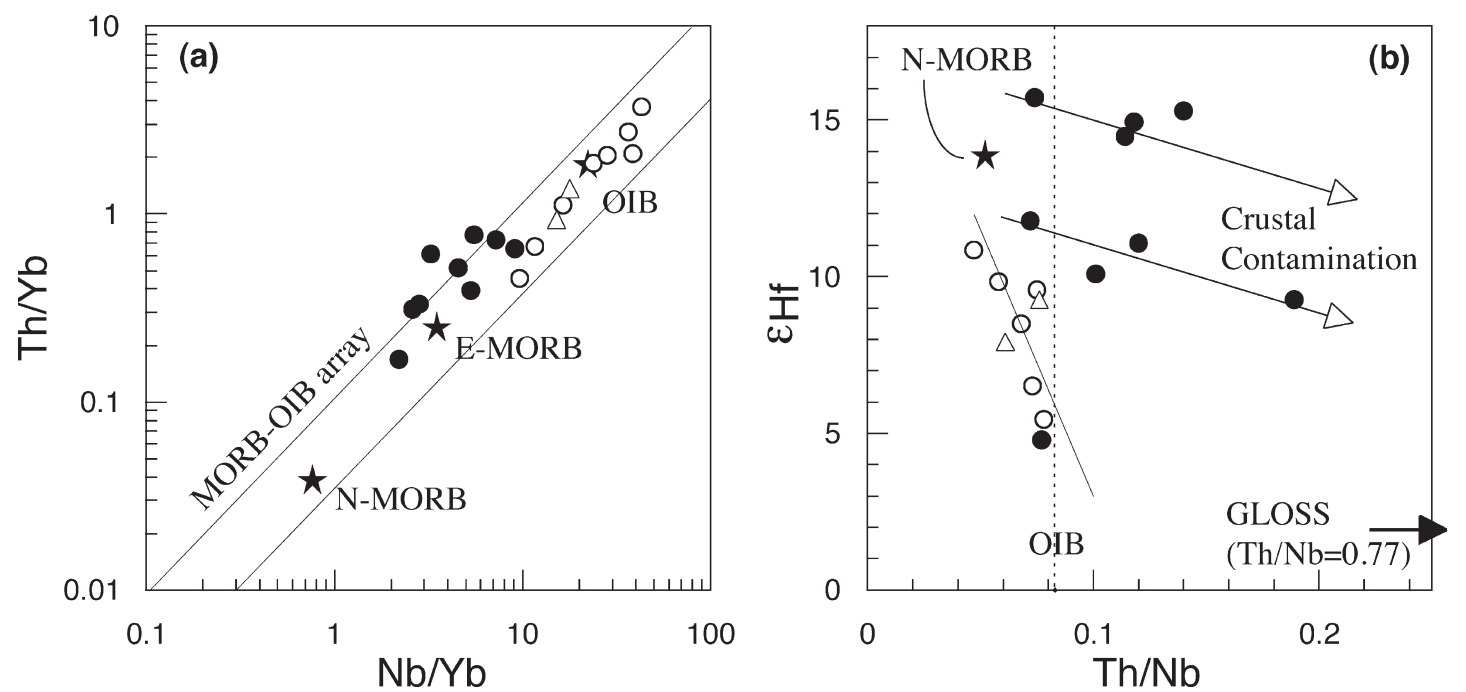

Figure 4. (a) $\mathrm{Th} / \mathrm{Yb}$ versus $\mathrm{Nb} / \mathrm{Yb}$ diagram (Pearce, 2008). A star indicates representative oceanic basalts (N-MORB, E-MORB, and OIB; all obtained from Sun and McDonough, 1989). The other symbols are the same as those in Figure 2. (b) $\varepsilon H f$ versus Th/Nb diagram. $\varepsilon H f$ values of N-MORB (+13.9) and average global subducting sediment (GLOSS) (+2) are obtained from Chauvel et al. (2008). Th/Nb values for GLOSS (0.77) and N-MORB and OIB (shown as thin dashed lines) are obtained from Plank and Langmuir (1998) and Sun and McDonough (1989), respectively. Arrows indicate the possible crustal contamination effect.

Figure 3 appear to correspond to components $1(\mathrm{C} 1)$ and 2 (C2) that were proposed in Meshesha and Shinjo (2008) as end-member components within the Afar mantle plume. Based on the compilation of $\mathrm{Sr}-\mathrm{Nd}-\mathrm{Pb}$ isotopic data for mafic rocks from the Yemen plateau, Ethiopian plateau, and northern Kenya rift published by Meshesha and Shinjo (2008), sample TL-253 of the Bure transitional tholeiite basalt has $\mathrm{Sr}-\mathrm{Nd}-\mathrm{Pb}$ isotopic compositions similar to those of the proposed $\mathrm{C} 1$ composition, whereas the Bure Oligocene alkaline basalts exhibit a C2-dominated composition. Therefore, the interaction of magmas, which were derived from the $\mathrm{C} 1-$ and $\mathrm{C} 2$-dominated mantle domains within the upwelling plume, with crustal materials at shallow levels can produce transitional tholeiitic basalts having lower $\mathrm{Nb} / \mathrm{La}$ and $\mathrm{Ce} / \mathrm{Pb}$.

Pearce (2008) proposed the usefulness of the $\mathrm{Th} / \mathrm{Yb}$ versus $\mathrm{Nb} / \mathrm{Yb}$ plot to assess the effect of crustal input on magma genesis of MORB and OIB (Fig. 4a). In Fig. 4a, although the alkaline basalts plot well within the "MORB-OIB array," many transitional tholeiites tend to have a higher $\mathrm{Th} / \mathrm{Yb}$ relative to the array, suggesting crustal input in the latter magmas. In Figure $4 b$, $\varepsilon \mathrm{Hf}$ of transitional tholeiites is broadly and negatively correlated with $\mathrm{Th} / \mathrm{Nb}$. Since high $\mathrm{Th} / \mathrm{Nb}$ and low $\varepsilon \mathrm{Hf}$ character is typical feature of crustal materials, crustal contamination overprint is thus also inferred for the Bure transitional tholeiites.

One may argue that a subcontinental lithosperic mantle (SCLM) is one of the contaminant components for the transitional tholeiite basalts (dashed arrow in Fig 3).
In this case, we may expect an SCLM component characterized by high $\varepsilon \mathrm{Hf}$. Indeed, clinopyroxene separates from Jordanian mantle xenoliths, which are thought to represent the lithospheric mantle in the region, and have compositions characterized by high \&Hf (average compositions are shown in Fig. 3; Shaw et al., 2007). The broad (or even scattered) data distribution of the transitional tholeiites in the $\varepsilon \mathrm{Hf} \mathrm{vs} . \mathrm{Nb} / \mathrm{La}$ plot does not trend toward high $\varepsilon \mathrm{Hf}$ (as reflected by cpx in the mantle xenolith) at the low $\mathrm{Nb} / \mathrm{La}$ side. This indicates that the interaction of magmas with lithospheric mantle like Jordanian mantle xenoliths is unlikely.

Although no Hf isotope data is available for the Ethiopian lithospheric mantle, a compilation by Nowell et al. (2004; see their Fig. 7) of $\varepsilon \mathrm{Hf}-\varepsilon \mathrm{Nd}$ data for peridotite minerals and whole-rocks of old oceanic lithosphere, cratonic, and non-cratonic continental lithospheric mantles demonstrated that most data plots are well above the $\mathrm{Nd}^{-}$ $\mathrm{Hf}$ isotope "mantle array" defined by oceanic basalts, i.e., most have positive $\Delta \varepsilon H f$ values. If this is the case for the lithospheric mantle beneath Ethiopia, the lack of a tendency to have higher $\Delta \varepsilon H f$ for basalts having low $\mathrm{Nb} / \mathrm{La}$ suggests that lithospheric involvement is less likely to explain the observed isotope variations of the transitional tholeiite suite.

In any case, Hf isotope ratios appear to be less sensitive to the crustal contamination effect, at least in the case of Bure basalts. This notion could be supported by nondistinctive Hf isotopic compositions for the Quaternary trachyte plug samples. The trachytes have Hf isotopic 

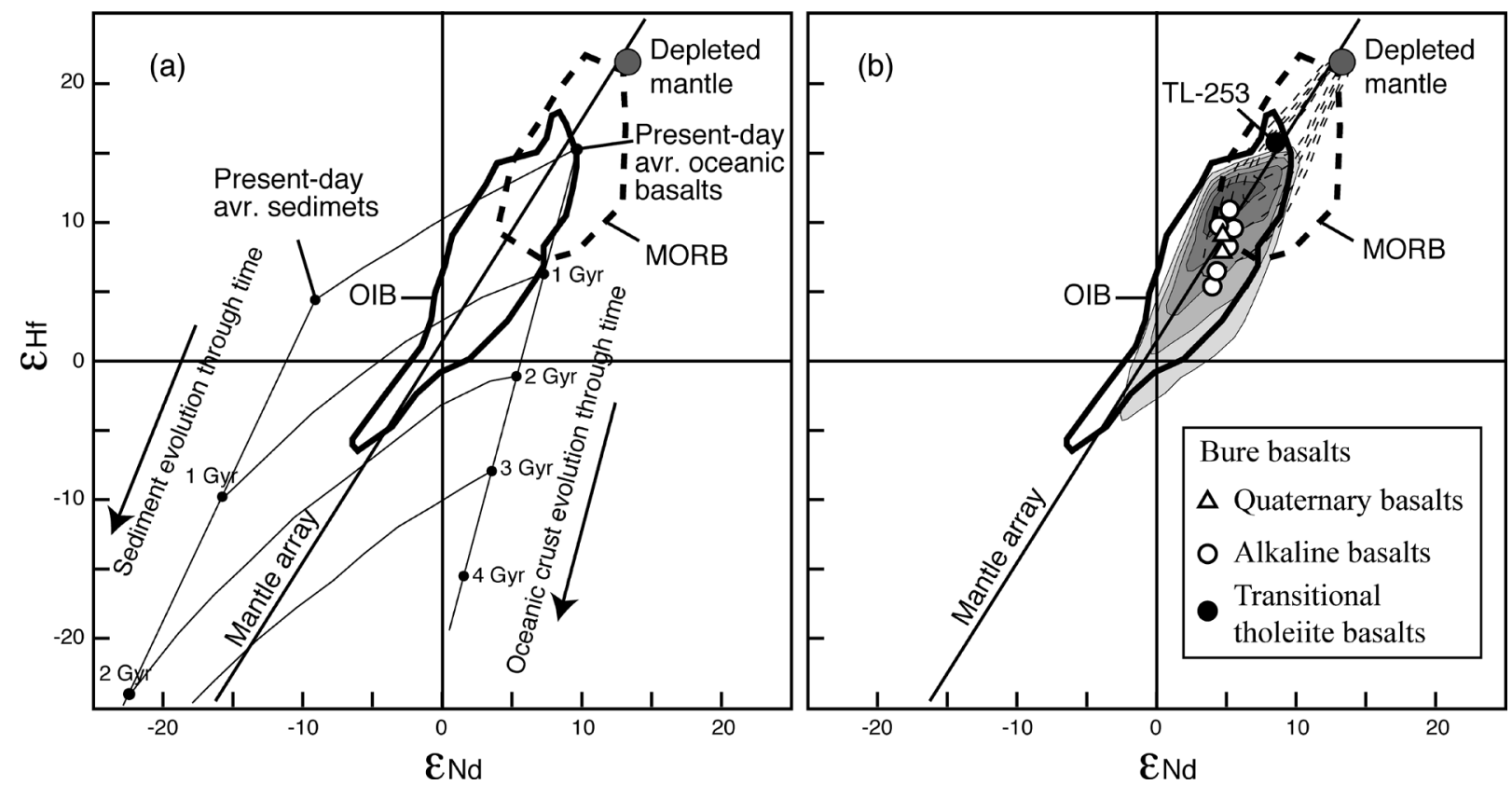

Figure 5. $\varepsilon H f$ versus $\varepsilon N d$ diagram comparing the Bure alkaline and tholeiitic basalts, worldwide OIB and MORB data, and the simulation results reported by Chauvel et al. (2008). Fields outlined by a thick dashed line and thick solid line indicate MORB and OIB data fields, respectively (obtained from Figure 1 of Chauvel et al., 2008). The present-day average compositions of oceanic basalt and sediments are shown in (a), together with their evolution paths during Earth's history; the mixing array between sediments and basalt (indicated by curves) represents recycled material. In (b), thin-solid counter lines (shaded gray) and thin-dashed counter lines indicate outlines of density plots for simulated OIB and MORB. All the parameters in (a) and (b) are adopted from Chauvel et al. (2008). For a proportion of recycled material ( $3 \mathrm{Gyr}<$ age $<0$ Gyr) of $20-30 \%$ relative to $70-80 \%$ depleted peridotite, the field of calculated values overlaps well with the OIB compositions, whereas the calculated results for $0-15 \%$ proportion of recycled material with $85-100 \%$ peridotite correspond to MORB compositions.

compositions similar to the Oligocene basalts, despite their unusually high ${ }^{87} \mathrm{Sr} /{ }^{86} \mathrm{Sr}$ (0.72153 and 0.73773; Meshesha and Shinjo, 2007); the high ${ }^{87} \mathrm{Sr}{ }^{86} \mathrm{Sr}$ characteristic is likely to result from the extensive crustal assimilation.

\section{Diversity of plume end-member compositions}

In Figure 2, the Bure alkaline basalt data extends towards the HIMU-like mantle end-member (Salter and White, 1998; Zindler and Hart, 1986; Armienti and Gasperini, 2007). Their geochemical compositions appear to remain unaffected by SCLM and crustal material contamination (Fig. 3); both $\mathrm{Nb} / \mathrm{La}$ and $\mathrm{Ce} / \mathrm{Pb}$ ratios are within the range of mantle values. Therefore, the alkaline basalts require a distinct mantle source having typical low ${ }^{176} \mathrm{Hf} /{ }^{177} \mathrm{Hf}$ and ${ }^{87} \mathrm{Sr} /{ }^{86} \mathrm{Sr}$ and high $\mathrm{Pb}$ isotopes. These contrasting variations of ${ }^{176} \mathrm{Hf} /{ }^{177} \mathrm{Hf}$ confirm that the Bure basalts are compositionally heterogeneous and the variations are indicative of long-lived source characteristics similar to the heterogeneities observed in the Hawaii (Blichert-Toft et al., 1999) and Galapagos (Geldmatcher et al., 2003; Blichert-Toft and White, 2001) plumes.

The alkaline basalts characterized by radiogenic $\mathrm{Pb}$ isotope $\left({ }^{206} \mathrm{~Pb} /{ }^{204} \mathrm{~Pb}=19.450\right.$ to 19.833$)$ have low $\varepsilon \mathrm{Hf}$ (3.9 to 5.56) and $\Delta \varepsilon \mathrm{Hf}(-0.54$ to -2.03$)$. These values are not typical to HIMU OIB, which have specifically lower $\varepsilon \mathrm{Hf}$ relative to the mantle array, as shown by St. Helena basalts. Therefore, Meshesha and Shinjo (2007) suggested that the end-member component inferred for alkali basalts resembles the common (C; Hanan and Graham, 1996) or focal zone (FOZO; Hart et al., 1992; Stracke et al., 2005) isotopic signature relative to HIMU and MORB fields.

In order to reproduce characteristic primitive mantle (PM)-normalized incompatible element patterns of alkali basalt, Meshesha and Shinjo (2008) performed model melt calculation by assuming $10 \%$ batch partial melting of a mixed source consisting of $20 \%$ recycled material and $80 \%$ PM matrix; they examined three types of recycled components including (1) 100\% dehydrated MORB, (2) $100 \%$ unaltered MORB, and (3) $95 \%$ unaltered MORB $+5 \%$ dehydrated sediment. When $100 \%$ unaltered MORB is assumed as a recycled crust, the calculation can reproduce smooth trace-element patterns having peaks at $\mathrm{Nb}$-Ta that resembles the alkaline basalts (see model melt 2 in Fig. 5 of Meshesha and Shinjo, 2008).

In Figure $4 \mathrm{a}$, the alkaline basalts plot well within the "MORB-OIB array" of Pearce (2008), who pointed out that the data trend toward high $\mathrm{Th} / \mathrm{Yb}$ above the array implies shallow-level crustal contamination or "a large" 
amount of deep-crustal recycling component in the source. In Fig. 4b, Bure alkaline basalts appear to form a steep negative trend, which is easily distinguishable from the trend of shallow-level crustal contamination for the transitional tholeiites. Low $\varepsilon \mathrm{Hf}$ and high $\mathrm{Th} / \mathrm{Nb}$ end-components may approach the GLOSS [global subducting sediment (Plank and Langmuir, 1998); Th/ $\mathrm{Nb}=0.77$ ] with average $\varepsilon H f$ of $+2( \pm 3)$ (Chauvel et al., 2008). This implies that the contribution of a subtle amount of subducted sediment component into the Oligocene alkaline basalt source may occur. Hanyu and Nakamura (2000) and Chauvel et al. (2008) have argued that the HIMU source cannot be formed only by a recycled oceanic crust and it may contain recycled oceanic sediments as reflected by its low $\varepsilon N d$.

Petrological constraints (e.g., Sobolev et al., 2007) indicate that OIBs are not created by the melting of basalt and sediments alone; peridotite must also be present in the source. To provide quantitative constraints on the relative amounts of sediment, oceanic crust, and upper mantle that need to be mixed to explain the Hf-Nd mantle array, Chauvel et al. (2008) conducted a simulation of the composition of the subducted crust as a random mixture of oceanic basalt and sediment in different proportions and from different times in Earth's history (Fig. 5). The calculated result forms a band of compositions that overlaps the mantle array; the field of calculated values of mixture of $20-30 \%$ of recycled material (consisting of $<20 \%$ sediment and $>80 \%$ basalt; both are up to 3 Gyr old) relative to $70-80 \%$ peridotite covers the compositions of OIB remarkably well.

Taking into account the result of modeling carried out by Chauvel et al. (2008), the diversity of end-member components inferred for the Bure basalt sources is considered to be controlled by several factors including (1) mixing proportion of recycled materials relative to peridotite, (2) proportion of sediment within the recycled materials (sediment-basalt mixture), and (3) formation age of recycled materials. Although a quantitative modeling approach is not performed here due to the uncertainty of these factors, component $2(\mathrm{C} 2)$ represented by the Bure low- $\varepsilon \mathrm{Hf}$ alkali basalts appears to reflect a higher proportion and/or older recycled material in the mixture of the mantle domain, as compared to component 1 (C1) observed in the less-contaminated tholeiitic basalts (sample TL-253) (Fig. $5)$.

\section{CONCLUDING REMARKS}

${ }^{177} \mathrm{Hf} /{ }^{176} \mathrm{Hf}$ of transitional tholeiite basalts are variable, ranging from $0.282901(\varepsilon \mathrm{Hf}=4.79)$ to $0.283206(\varepsilon \mathrm{Hf}=$ 15.71), and more heterogeneous than the alkaline basalts, which have a relatively limited range of ${ }^{177} \mathrm{Hf} /{ }^{176} \mathrm{Hf}$ of $0.282915(\varepsilon \mathrm{Hf}=5.45)$ to $0.283069(\varepsilon \mathrm{Hf}=10.85)$. The transitional tholeiite basalts are characterized by two groups that have relatively lower and higher ${ }^{177} \mathrm{Hf} /{ }^{176} \mathrm{Hf}$ isotope ratios. These signatures can be mainly explained by crustal contamination of magmas that were derived from two different plume sources.

Our new Hf isotope data provides an Hf isotopic signature for two end-member components inferred in the Afar mantle plume (Meshesha and Shinjo, 2008); components $1(\mathrm{C} 1)$ and 2 (C2) of Meshesha and Shinjo (2008) have $\varepsilon \mathrm{Hf}=15-17$ and 5-9, respectively. The diversity of the source compositions could be controlled by the proportion of recycled materials in the deep mantle, its formation age, and mixing ratios of oceanic crust and sediments in recycled materials. The $\mathrm{C} 2$ source appears to be characterized by a higher proportion of recycled materials and/or older recycled materials than those in the $\mathrm{C} 1$ source.

\section{ACKNOWLEDGMENTS}

D. M. thanks Japan Society for the Promotion of Science (JSPS) for Postdoctoral Fellowship for Foreign Researchers and the Japanese Ministry of Education, Culture, Sports, Science and Technology (MEXT) for a scholarship from the "Special Graduate Program for International Students" at the University of the Ryukyus. We thank Sun-Lin Chung and Sylvain Gallet of the National Taiwan University for operating the MC-ICP-MS. We also thank Shigeru Ohde (University of the Ryukyus) for assistance with the TIMS measurements. We thank the Geological Survey of Ethiopia (GSE) for the considerable support provided by them. R. S. was supported by the MEXT grants 17540458 (C) and 21540496 (C). We thank the two reviewers, T. Hanyu and Y. Orihashi, and the journal associate editor, J.I. Kimura, for their constructive comments on the submitted manuscript.

\section{REFERENCES}

Armienti, P. and Gasperini, D. (2007) Do we really need mantle components to define mantle composition? Journal of Petrology, 48, 693-709.

Ayalew, D., Barbey, P., Marty, B., Reisberg, L., Yirgu, G. and Pik, R. (2002) Source, genesis, and timing of giant ignimbrite deposits associated with Ethiopian continental flood basalts. Geochimica et Cosmochimica Acta, 66, 1429-1448.

Baker, J., Thirlwall, M. and Menzies, M. (1996) Sr-Nd-Pb isotopic and trace element evidence for crustal contamination of plume-derived flood basalts: Oligocene flood volcanism in western Yemen. Geochimica et Cosmochimica Acta, 60, 25592581.

Baker, J., MacPherson, C.G., Menzies, M.A., Thirlwall, M.F., Al- 
Kadasi, M. and Mattey, D.P. (2000) Resolving crustal and mantle contributions to continental flood volcanism, Yemen; constraints from mineral oxygen isotope data. Journal of Petrology, 41, 1805-1820.

Ballentine, C.J., Lee, D.-C. and Halliday, A.N. (1997) Hafnium isotopic studies of the Cameroon line and new HIMU paradoxes. Chemical Geology, 139, 111-124.

Berhe, S., Desta, B., Nicoletti, M. and Tefera, M. (1987) Geology, geochronology and geodynamic implications of the Cenozoic magmatic province in $\mathrm{W}$ and SE Ethiopia. Journal of Geological Society London, 144, 213-226.

Bertrand, H., Chazot, G., Blichert-Toft, J. and Thoral, S. (2003) Implications of widespread high- $\mu$ volcanism on the Arabian Plate for Afar mantle plume and lithosphere composition. Chemical Geology, 198, 47-61.

Bizzarro, M., Baker, J.A., Haack, H., Ulfbeck, D. and Rosing, M. (2003) Early history of Earth's crust-mantle system inferred from hafnium isotopes in chondrites. Nature, 421, 931-933.

Blichert-Toft, J. and Albarède, F. (1997a) The Lu-Hf isotope geochemistry of chondrites and the evolution of the mantle-crust system. Earth and Planetary Science Letters, 148, 243-258.

Blichert-Toft, J., Chauvel, C. and Albarède, F. (1997b) Separation of $\mathrm{Hf}$ and $\mathrm{Lu}$ for high-precision isotope analysis of rock samples by magnetic sector-multiple collector ICP-MS. Contributions to Mineralogy and Petrology, 127, 248-260.

Blichert-Toft, J., Frey, F.A. and Albarède, F. (1999) Hf isotope evidence for pelagic sediments in the source of Hawaiian basalts. Science, 285, 879-882.

Blichert-Toft, J. and White, W.M. (2001) Hf isotope geochemistry of the Galapagos islands. Geochemistry Geophysics Geosystems, 2, doi:10.1029/2000GC000138.

Chauvel, C. and Blichert-Toft, J. (2001) A hafnium isotope and trace element perspective on melting of the depleted mantle. Earth and Planetary Science Letters, 190, 137-151.

Chauvel, C., Lewin, E., Carpentier, M., Arndt, N.T. and Marini, J.-C. (2008) Role of recycled oceanic basalt and sediment in generating the Hf-Nd mantle array. Nature Geoscience, 1, 64-67, doi:10.1038/ngeo.2007.51.

Chazot, G. and Bertrand, H. (1993) Mantle Sources and MagmaContinental Crust Interactions During Early Red Sea-Gulf of Aden Rifting in Southern Yemen: Elemental and $\mathrm{Sr}, \mathrm{Nd}, \mathrm{Pb}$ Isotope Evidence. Journal of Geophysical Research, 98, 1819-1835.

Coulie, E., Quidelleur, X., Gillot, P.-Y., Courtillot, V., Lefèvre, J.-C. and Chiesa, S. (2003) Comparative $\mathrm{K}-\mathrm{Ar}$ and $\mathrm{Ar} / \mathrm{Ar}$ dating of Ethiopian and Yemenite Oligocene volcanism: implications for timing and duration of the Ethiopian traps. Earth and Planetary Science Letters, 206, 477-492.

Davidson, A. and Rex, D.C. (1980) Age of volcanism and rifting in southern Ethiopia. Nature, 283, 657-558.

Ebinger, C., Yemane, T., WoldeGabriel, G., Aronson, J. and Walter, R. (1993) Eocene-Recent volcanism and faulting in the southern Main Ethiopian Rift. Journal of the Geological Society, London, 150, 99-108.

Furman, T. (2007) Geochemistry of East African Rift basalts: An overview. Journal of African Earth Science, 48, 147-160.

Geldmacher, J., Hanan, B.B., Blichert-Toft, J., Harpp, K., Hoernle, K., Hauff, F., Werner, R. and Kerr, A.C. (2003) Hafnium isotopic variations in volcanic rocks from the Caribbean Large Igneous Province and Galapagos hot spot tracks. Geochemistry Geophysics Geosystems, 4, doi:10.1029/2002GC 000477.
George, R., Rogers, N. and Kelley, S. (1998) Earliest magmatism in Ethiopia: evidence for two mantle plumes in one flood basalt province. Geology, 26, 923-926.

George, R.M. and Rogers, N.W. (2002) Plume dynamics beneath the African plate inferred from the geochemistry of the Tertiary basalts from southern Ethiopia. Contributions to Mineralogy and Petrology, 144, 286-304.

Hanan, B.B. and Graham, D.W. (1996) Lead and helium isotope evidence from oceanic basalts for a common deep source of mantle plumes. Science, 272, 991-995.

Hanyu, T. and Nakamura, E. (2000) Constraints on HIMU and $\mathrm{EM}$ by $\mathrm{Sr}$ and $\mathrm{Nd}$ isotopes re-examined. Earth Planets Space, 52, 61-70.

Hart, S.R., Hauri, E.H., Oschmann, L.A. and Whitehead, J.A. (1992) Mantle plumes and entrainment-Isotopic evidence. Science, 256, 517-520.

Hofmann, A.W., Jochum, K.P., Seufert, H.M. and White, W.M. (1986) $\mathrm{Nb}$ and $\mathrm{Pb}$ in oceanic basalts: New constraints on mantle evolution. Earth and Planetary Science Letters, 79, 33-45.

Hofmann, C., Courtillot, V., Féraud, G., Rochette, P., Yirgu, G., Ketefo, E. and Pik, R. (1997) Timing of the Ethiopian flood basalt event and implications for plume birth and global change. Nature, 389, 838-841.

Jacobsen, S.B. and Wasserburg, G.J. (1980) Sm-Nd isotopic evolution of chondrites. Earth and Planetary Science Letters, 50, 139-155.

Janney, P.E., Le Roex, A.P., Carlson, R.W. and Viljoen, K.S. (2002) A chemical and multi-isotope study of the Western Cape melilitite province, South Africa: implications for the sources of kimberlites and the origin of the HIMU signature in Africa. Journal of Petrology 43, 2339-2370.

Janney, P.E., Le Roex, A.P and Carlson, R.W. (2005) Hafnium Isotope and Trace Element Constraints on the Nature of Mantle Heterogeneity beneath the Central Southwest Indian Ridge $\left(13^{\circ} \mathrm{E}\right.$ to $\left.47^{\circ} \mathrm{E}\right)$. Journal of Petrology, 46, 2427-2464.

Kieffer, B., Arndt, N., Lapierre, H., Bastien, F., Bosch, D., Pecher, A., Yirgu, G., Ayalew, D., Weis, D., Jerram, D.A., Keller, F. and Meugniot, C. (2004) Flood and Shield Basalts from Ethiopia: Magmas from the African Superswell. Journal of Petrology, 45, 793-834.

Lapen, T.J., Mahlen, N.J., Johnson, C.M and Beard, B.L. (2004) High precision $\mathrm{Lu}$ and $\mathrm{Hf}$ isotope analyses of both spiked and unspiked samples: A new approach. Geochemistry Geophysics Geosystems, Q01010, doi:10.1029/2003GC000582.

Marty, B., Pik, R. and Gezahegn, Y. (1996) Helium isotopic variations in Ethiopian plume lavas: nature of magmatic sources and limit on lower mantle contribution. Earth and Planetary Science Letters, 144, 223-237.

Meshesha, A.D. and Shinjo, R. (2004) Petrochemical evidence for diversity of magma compositions at the northwestern Ethiopian volcanic province. Bulletin of the Faculty of Science, University of the Ryukyus, 78, 251-266.

Meshesha, D. and Shinjo, R. (2007) Crustal contamination and diversity of magma sources in the northwestern Ethiopian volcanic province. Journal of Mineralogical and Petrological Science, 102, 272-290.

Meshesha, D. and Shinjo, R. (2008) Rethinking geochemical feature of Afar and Kenya plumes and geodynamic implications. Journal of Geophysical Research, doi:10.1029/2007JB 005549.

Mohr, P.A. (1963) The Geology of Ethiopia. pp. 268, Addis Ababa 
University Press, Addis Ababa, Ethiopia.

Mohr, P. and Zanettin, B. (1988) The Ethiopian flood basalt province. In Continental flood basalts (McDougall, J.D. Ed.). Kluwer Acadamic Publication, Dordrecht, 63-110.

Münker, C., Weyer, S., Scherer, E. and Mezger, K. (2001) Separation of high field strength elements (Nb, Ta, $\mathrm{Zr}, \mathrm{Hf}$ ) and $\mathrm{Lu}$ from rock samples for MC-ICPMS measurements. Geochemistry Geophysics Geosystems, 2, doi: 10.1029/2001GC 000183.

Nelson, W.R., Furman, T., Hanan, B. (2008) Sr, Nd, Pb and Hf evidence for two-plume mixing beneath the East African Rift System. Geochimica et Cosmochimica Acta, 72, No 12S, Goldschmidt 2008 Conference Abstracts, A676.

Nowell, G.M., Kempton, P.D., Noble, S.R., Fitton, J.G., Saunders, A.D., Mahoney, J.J. and Taylor, R.N. (1998) High precision $\mathrm{Hf}$ isotope measurements of MORB and OIB by thermal ionisation mass spectrometry insights into the depleted mantle. Chemical Geology, 149, 211-233.

Nowell, G.M., Pearson, D.G., Bell, D.R., Carlson, R.W., Smith, C.B., Kempton, P.D. and Noble, S.R. (2004) Hf isotope systematics of kimberlites and their megacrysts: new constraints on their source regions. Journal of Petrology, 45, 1583-1612.

Pearce, J.A. (2008) Geochemical fingerprinting of oceanic basalts with applications to ophiolite classification and the search for Archean oceanic crust. Lithos, 100, 14-48.

Pik, R., Deniel, C., Coulon, C., Yirgu, G., Hoffmann, C. and Ayalew, D. (1998) The northwestern Ethiopian Plateau flood basalts: Classification and spatial distribution of magma types. Journal of Volcanology and Geothermal Research, 81, 91-111.

Pik, R., Deniel, C., Coulon, C., Yirgu, G., Hoffmann, C. and Ayalew, D. (1999) Isotopic and trace element signatures of Ethiopian flood basalts: evidence for plume-lithosphere interactions. Geochimica et Cosmochimica Acta, 63, 2263-2279.

Plank, T. and Langmuir, C.H. (1998) The chemical composition of subducting sediment and its consequences for the crust and mantle. Chemical Geology, 145, 325-394.

Rooney, T., Hanan, B., Graham, D. and Furman, T. (2007) The Afar plume and Ethiopian lithosphere: a Hf and He isotope study of primitive Quaternary rift lavas. American Geophysical Union, Fall Meeting 2007, abstract \#V33A-1166.

Rooney, T., Hanan, B., Furman, T. and Graham, D. (2008) Multicomponent isotopic mixing in the Ethiopian Rift: Modeling plume contributions to recent magmatism. Geochimica et Cosmochimica Acta, 72, No 12S, Goldschmidt 2008 Conference Abstracts, A804.

Rudnick, R.L. and Gao, S. (2004) Composition of the continental crust, In Treatise on Geochemistry, vol. 3, The Crust (Rud- nick, R.L. Ed.). Elsevier, New York, 1-66.

Salters, V.J.M. and White, W.M. (1998) Hf isotope constraints on mantle evolution. Chemical Geology, 145, 447-460.

Shaw, J.E., Baker, J.A., Kent, A.J.R., Ibrahim, K.M. and Menzies, M.A. (2007) The Geochemistry of the Arabian Lithospheric Mantle: - a Source for Intraplate Volcanism? Journal of Petrology, 48, 1495-1512.

Sobolev, A.V., Hofmann, A.W., Kuzmin, D.V., Yaxley, G.M., Arndt, N.T., Chung, S.-L., Danyushevsky, L.V., Elliott, T., Frey, F.A., Garcia, M.O., Gurenko, A.A., Kamenetsky, V.S., Kerr, A.C., Krivolutskaya, N.A., Matvienkov, V.V., Nikogosian, I.K., Rocholl, A., Sigurdsson, I.A., Sushchevskaya, N.M. and Teklay, M. (2007) The amount of recycled crust in sources of mantle-derived melts. Science, 316, 412-417.

Stracke, A., Hofmann, A.W. and Hart, S.R. (2005) FOZO, HIMU, and the rest of the mantle zoo. Geochemistry Geophysics Geosystems, 6, Q05007, doi:10.1029/2004 GC000824.

Sun, S.S. and McDonough, W.F. (1989) Chemical and isotopic systematics of oceanic basalts: implications for mantle composition and processes. In Magmatism in oceanic basins (Saunders, A.D. and Norry, M.J. Eds.). Geological Society of London, Special Publication, 42, 313-345.

Taylor, R.S. and McLennan, S.M. (1985) The Continental Crust: Its Composition and Evolution. Blackwell, Malden, Mass.

Ukstins, I.A., Renne, P.R., Wolfenden, E., Baker, J., Ayalew, D. and Menzies, M. (2002) Matching conjugate volcanic rifted margins: ${ }^{40} \mathrm{Ar} /{ }^{39} \mathrm{Ar}$ chrono-stratigraphy of pre- and syn-rift bimodal flood volcanism in Ethiopia and Yemen. Earth and Planetary Science Letters, 198, 289-306.

Vervoort, J.D. and Blichert-Toft, J. (1999) Evolution of the depleted mantle: Hf isotope evidence from juvenile rocks through time. Geochimica et Cosmochimica Acta, 63, 533-559.

Vervoort, J.D., Patchett, P.J., Albarède, F., Blichert-Toft, J., Rudnick, R. and Downes, H. (2000) Hf-Nd isotopic evolution of the lower crust. Earth and Planetary Science Letters, 181, 115-129.

WoldeGabriel, G., Aronson, J.L. and Walter R.C. (1990) Geology, geochronology, and rift basin development in the central sector of the Main Ethiopian Rift. Geological Society of America Bulletine, 102, 439-458.

Zindler, A. and Hart, S.R. (1986) Chemical geodynamics. Annual Revision of Earth and Planetary Science Letters, 14, 493571.

Manuscript received April 27, 2009

Manuscript accepted October 20, 2009

Published online February 5, 2010

Manuscript handled by Jun-Ichi Kimura 